\title{
Research on Innovation of Ideological and Political Education Mechanism in Colleges and Universities
}

\author{
Yang Jing \\ Urban Vocational College of Sichuan, Chengdu, Sichuan, 610110
}

Keywords: ideological education mechanism; higher education; innovation

\begin{abstract}
With the development of economy and society, great changes have taken place in China's higher education. However, in the education process, we have not fundamentally changed the mechanism of ideological and political education for college students, which has affected the effectiveness of ideological and political education. Based on the analysis of existing problems in traditional ideological and political education mechanism, this paper puts forward the idea of innovation in ideological and political education mechanism for college students.
\end{abstract}

\section{Introduction}

The ideological and political education mechanism is the intrinsic working method in the process of ideological and political education and the mutual connection of various factors. Only through certain methods can we gradually translate the goals of ideological and political education into the intrinsic needs and motives of educated people, and enable educators to translate this motivation into behavior to obtain good educational effects. Therefore, the education mechanism is also an intermediary and a bridge to achieve educational goals. For a long time, the ideological and political education in colleges and universities has paid more attention to the construction of goals, contents, and methods. However, the internal operational mechanism of ideological and political education has not been studied enough, which has affected the effectiveness of ideological and political education.

\section{Theoretical Basis for Institutional Innovation of Ideological and Political Education in Colleges and Universities}

In 2004, it was called "Ideological Year". In this year, the Central Document No. 8 and No. 16 introduced strengthening and improving ideological and moral construction and strengthening and improving the direction of ideological and political education. In Document No. 8, the guiding ideology, basic principles, and major tasks for strengthening and improving ideology and morality of minors were proposed. Document No. 16 put forward important suggestions for giving full play to the role of the Party in ideological and political education, clarified the guiding ideology, principles, and specific methods of work for strengthening and improving the ideological and political education of university students, and further improved the ideological and political education of top-level design.

2010 marks the 6th anniversary of the release of the 16th document. The party committee should attach great importance to ideological and political teachers. It is necessary to conscientiously sum up the implementation of the No. 16 document over the past six years and to earnestly sum up experience and practices. A detailed analysis of the new situations and new problems encountered in the work, and a full understanding of the new situation and new requirements facing the ideological and political education, in order to promote the spirit of the No.16 document, and further strengthen and improve ideological and political education. The teaching effect of the course. In colleges and universities, this teaching method should be promoted to promote observation, and after the exchange of lectures, relevant teachers should be organized for discussion. Only by combining actual theoretical and historical realities, social realities, and students' actual conditions can classroom teaching be persuasive and appealing. This will enable ideological and political educators 
to continuously accumulate teaching experience and improve their own teaching standards.

According to the new situation and tasks faced by the current ideological and political education, the main tasks of strengthening and improving ideological and political education are summarized as a whole, and the core of ideological and political education is clearly defined as idealism and beliefism. The emphasis is on patriotic education, which is based on the basic ethical norms of college students. The goal is to promote the overall development of college students. Through the above explanations, the main tasks of ideological and political education in colleges and universities are clarified, and the ideological and political education for college students is promoted in an all-round way. The CPC Central Committee and the State Council attach great importance to ideological and political education. Through the issuance of documents, conferences, and conference speeches, the leaders have attached great importance to the ideological and political education mechanism. Through the study of many documents, the ideological and political education mechanism for college students has been clearly defined. The main methods and practices have formed new ideas for establishing and improving the ideological and political education system for college students.

\section{The Realistic Basis for Institutional Innovation of Ideological and Political Education in Colleges and Universities}

In recent years, colleges and universities have increasingly attached importance to ideological and political education, attached great importance to cultivating outstanding builders and successors in the socialist cause, and constantly improved the ideological and political education mechanism in colleges and universities, and have achieved remarkable results. With the rapid development of market economy, the current ideological and political education mechanism has been unable to meet the needs of ideological and political education in universities. Therefore, we must innovate the ideological and political education mechanism. The achievements of past ideological and political education mechanisms have provided a realistic basis for this. The Communist Party organization undertook ideological and political responsibilities and led ideological and political education for college students. It initially formed the ideological and political education management mechanism. The school party committee put the problem of how to train college students and how to carry out ideological and political education for college students on top of the work, and provided theoretical guidance. We should make scientific plans, strengthen the building of ideological and political education teams and standardize the system, and at the same time improve and coordinate development. The Communist Party organization undertook ideological and political responsibilities and led ideological and political education for college students. It initially formed the ideological and political education management mechanism. The school party committee put the problem of how to train college students and how to carry out ideological and political education for college students on top of the work, and provided theoretical guidance. We should make scientific plans, strengthen the building of ideological and political education teams and standardize the system, and at the same time improve and coordinate development. In the report of the 18th National Congress of the Communist Party of China, education was emphasized: priority should be given to the development of education in social development. Human resources and power education is the cornerstone of national rejuvenation and education development. Education is an important foundation for social development. It is necessary to fully implement the Party's education policy and adhere to the people-oriented principle. The education always takes education as a priority, vigorously implements quality education, raises the level of modern education, fosters the builders and successors of all-round development of morality, intelligence, beauty, and beauty, and realizes citizens' satisfaction with education. Improve the overall quality of the teaching staff, especially the quality of rural teachers. Actively encourage and standardize social forces to start education. At present, some colleges and universities have comprehensively established assessment mechanisms that combine student evaluation with teaching supervision. Schools should also combine the evaluation of their work with the economic benefits of individuals. Through the establishment of a rigorous assessment system, the schools' schools and schools' guiding ideology 
is to evaluate the educational effectiveness of ideological and political educators as a whole and to put the party's education policy into practice. The real implementation of the ideological and political education to students. Improve the initiative and creativity of ideological and political educators, and clarify the objectives of ideological and political education for college students to ensure that the work of ideological and political education for college students is implemented.

\section{Conception and Innovation of Ideological and Political Education in Colleges and Universities}

The internal working methods of the ideological and political education process are diverse and have been fully proved in the ideological and political education practice in various countries. The choice of mechanism is a dynamic process. There is no permanent model. It is necessary to scientifically and actively select educational mechanisms based on the objective reality of economic and social development and human development, and to realize the innovation of mechanisms so as to ensure the goal of ideological and political education. achieve. However, the choice and innovation of the mechanism are not unfounded and arbitrary processes, but must follow certain principles. First, the mechanism innovation must be based on the principle of solving the basic contradiction of ideological and political education. That is to resolve the contradiction between educational requirements and the educated person's ideological and moral reality. Second, institutional innovation must reflect the basic laws of ideological and political education. The educational activities of educators must be adapted to the rules of the ideological and moral conditions of educated people. Third, mechanism innovation should reflect the characteristics of the ideological and political education process. Social, practical, versatile, repetitive. Fourth, institutional innovation must be coordinated with and promoted by the innovation of educational ideas, the innovation of educational content, and the innovation of educational methods.

Build self-discipline-centered college students' self-education mechanism. The cultivation of self-discipline consciousness is essentially the educator's self-education activity. Traditional ideological and political education activities also recognize the position and role of self-education in ideological and political education. However, in education practice, we have not formed the mechanism of self-education of college students or the mechanism of self-education is not perfect, resulting in a heavy emphasis on ideological and political education. Indoctrination, and sometimes even empty preaching, such educational goals are often impractical. Judging from the actual situation of college students' ideological and political education in Hebei Province, the ideological and political education activities focusing on the "two courses" have the problem of focusing on teaching and education, focusing on imparting knowledge and fostering moral character, and failing to give full play to the function of college students' self-education. And function. To build the mechanism of self-education for college students, it is necessary to thoroughly reform the teaching model of the political theory class, fully mobilize the enthusiasm and initiative of college students, and cultivate the students' ability to think, experience and self-select themselves, and reform the classroom teaching format and content. And methods that combine indoctrination and enlightenment, with a focus on enlightenment. Encourage political theory teachers to continuously explore and innovate in education and teaching activities, break through the "rigidity" framework of traditional ideological and political education, and change the teaching of political theory from knowledge transfer to the collaborative development of knowledge and ability.

The types of ideological and political education include political education, ideological education, moral education, and psychological education. The four aspects are of different nature and different tasks, which determine that the goals, methods, and ways of implementing education are different. This is determined by their own laws. Political education is mainly inculcated, ideological education is mainly enlightened, moral education is practiced, and psychological education is guided. If the theory and methods of political education are universally applied to ideological education, moral education, and psychological education, it is to use political education instead of everything, which is against the laws of ideological education, and of course it will not produce good results. With the development of the market economy, diversification of ownership 
and distribution methods, and diversification of interest patterns, social phenomena are presented in a complex and complicated situation, resulting in more and more psychological problems of college students. Under this background, improving the psychological quality of college students It seems to be more and more important, but education in this area is very weak: First, it has not put the psychological education in its proper place, and it is not well understood. Second, the lack of psychological education experience, lack of high-level teaching materials and high-quality teachers, and the third is not to establish a sound mechanism for the protection of psychological education in colleges and universities. Although most colleges and universities have set up specialized psychological counseling agencies, there is a big gap between the actual needs of psychological education. In fact, everyone has the need for psychological development. This requires psychological education and psychological counseling for all students. However, the goals and scope of psychological education cannot meet this demand.

\section{Conclusion}

Establishing a sound and long-term mechanism for ideological and political education plays a very important role in accomplishing the objectives of ideological and political education and achieving the expected results. It is an important aspect that is indispensable and can not be ignored in the ideological and political education of college students. Therefore, the mechanism of ideological and political education for undergraduates must be strengthened. Innovation research has important practical significance. On the other hand, the ideological and political education mechanism is a relatively complex and abstract theoretical issue. Since the overall research in this area is still relatively weak, the ideas, viewpoints, and arguments in this article still have many shortcomings and deficiencies. With the continuous development of ideological and political education in colleges and universities, a series of issues in ideological and political education, especially the study of innovation in educational mechanisms, will greatly promote the development of ideological and political work in colleges and universities, and cultivate a large number of socialist modernizations. Talent makes greater contributions.

\section{References}

[1] Zheng Ying. A preliminary study of party building and ideological and political work in the independent college [J]. Journal of the National School of Administration, 2005, (5).

[2] Zheng Jie, Zhang Yan. The exploration of the ideological and political education of students in private colleges and universities [J]. Journal of Zhejiang Shuren University, 2004, (4).

[3] Yang Zhangcheng. Analysis of the Contradiction between Capital Profit-Seeking and Education Public-Benefit in Private-owned Secondary Colleges [J]. Journal of Fujian Normal University, 2002, (3).

[4] Qi Nuo. Pay attention to strengthening the party building, ideological and political work and moral education in private universities [J]. Chinese Higher Education Research, 2001, (1).

[5] Yuan Guiren. Effectively strengthen and improve moral education in private universities [J]. Ideological and Theoretical Education, 2004, (4). 